\title{
ALEXANDER BURGANOV. IN THE DEPTHS ABOVE REALITY. (ANTIQUE MOTIFS IN THE CONTEXT OF CREATIVE WORK)
}

Summary: For decades, images of antiquity have appeared in the creative work of academician Alexander Burganov.

The sculptor declaratively emphasizes his focus on the cultural tradition which evolved from the cradle of Antiquity and which is, therefore, understandable to anyone who shares its humanistic ideals.

The article refers to his personal exhibitions and events of the last decades: "Dreams Within Us. A Magic Crystal" at the Moscow Central House of Artists in 1987, "Magic Realism" in Germany in 1993, "Antique Motifs in Modern Sculpture" in the Burganov House Museum at which he presented his "legends and myths of Ancient Greece" in 2017, and the exhibition held in the Antique Hall in the Museum of Archeology of the Westphalian Wilhelm University of Münster in 2013.

Works and cycles, never directly illustrating ancient mythology but unconsciously translating the archetypal, the transcendental through personal experience, a sen-

For four centuries, the pan-European art school has been built on the phased development of mastery, a curriculum which includes drawing classical plaster casts. Art historians and memoirists repeatedly recall the initial stages of the biographies of many contemporary (in the broadest sense of the definition, as it is accepted today - starting almost from impressionists) artists who deny and, moreover, reject this occupation as being a "meaningless" and "harmful" formation of artistic thinking. Meanwhile, truly famous names, whose biographies para- sory reaction, are considered. The frequent presence of Burganov's works of art in an "intermediate" state, in the process of transformation, which makes it easy to detect the surreal component, is their feature.

Burganov's "antique" sculptures organically exist not only in exhibition halls but also outside them - be it the courtyard of the Burganov House Museum or the square in Brussels where the sculptures in the window display of the Burganov House at the Grand Place are no less eye-catching than the monument in the same square. Noble restraint (with clearly readable spectacularity), bearing in itself, within itself, dreams and passions, reality and mysticism, gives Burganov's "antique" images-metaphors a special feature that requires comprehension of the slow, at the same time the reasonable and the emotional in order to be able to penetrate the limits of the immanent artist's impermeability.

Keywords: Alexander Burganov, antiquity, sculpture, surrealism, archetype, metaphor

doxically indicate an inverse attitude, can be named. For example, Pablo Picasso, Salvador Dali, Giorgio de Chirico. Moreover, these masters, whose involvement in "modernity" cannot be doubted, interpreted their own, private mythology through the images of antiquity; often, they persistently included images of ancient sculptural monuments, fragments of plaster casts in their compositions. Zadkine, Modigliani, Matisse can be included in a considerable list of masters of the European twentieth century in whose works antique motifs became noticeable and 


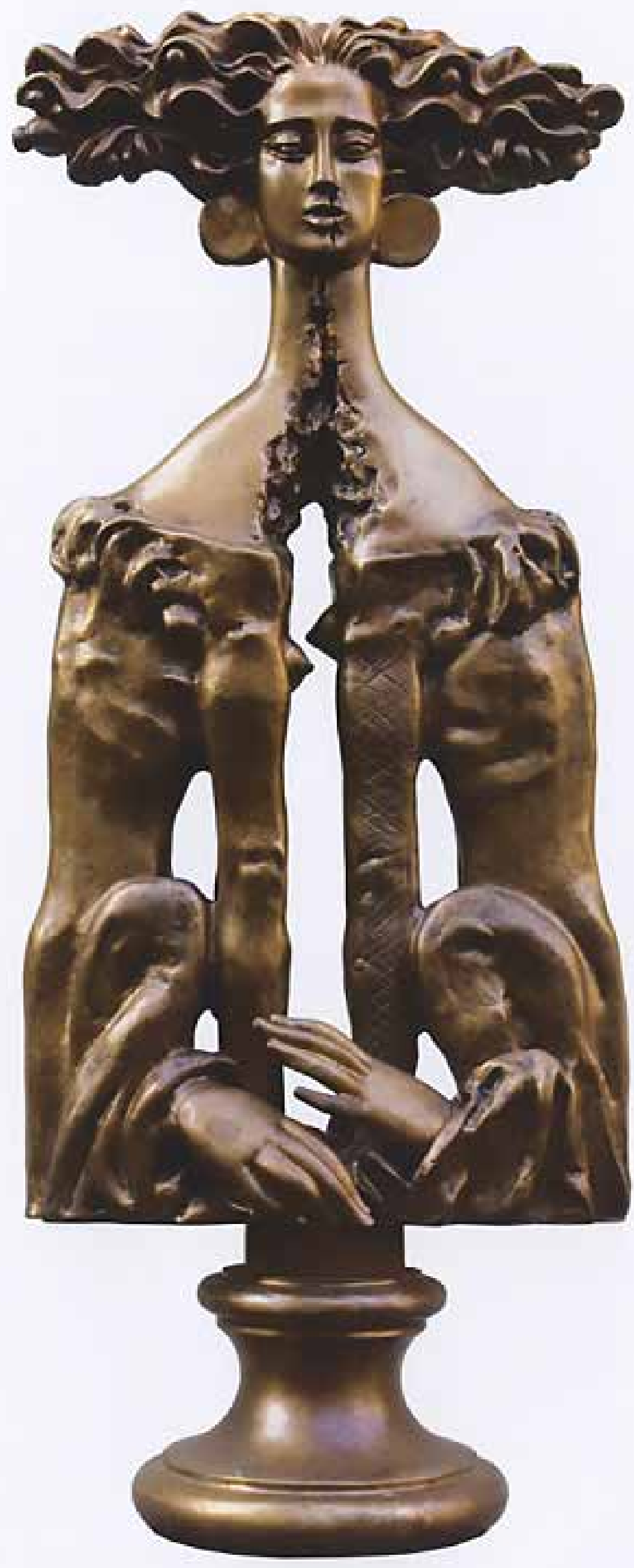




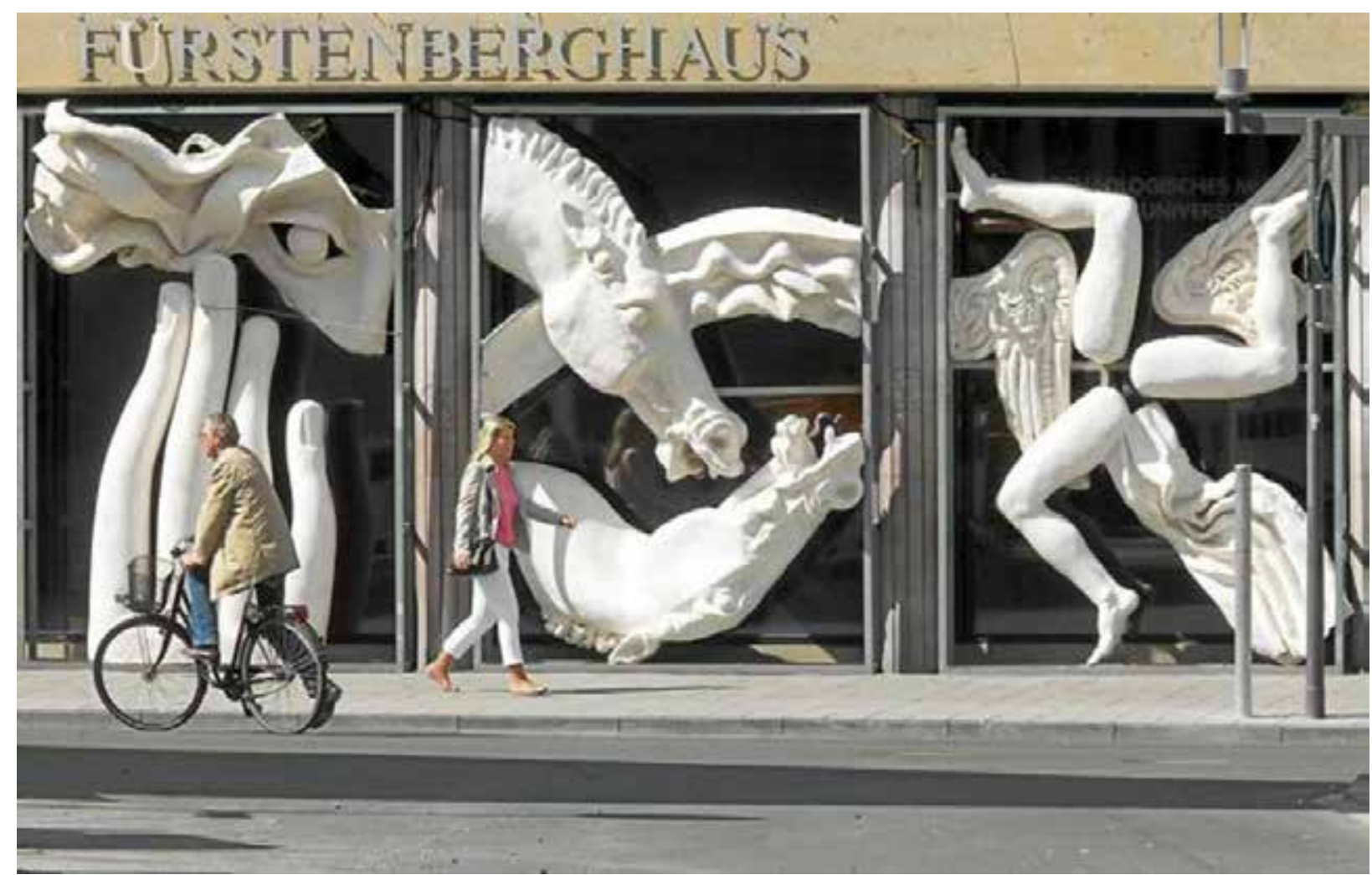

The Trojan War. Clay, metal. 2013. The composition was created specifically for Alexander Burganov's personal exhibition at the Wilhelm Museum of Archeology of the University of Westphalia in Münster. 2013

important outside the space of neoclassicism. Over many decades of their stay in the Soviet space, artists of Russia show only rare examples (in my opinion, the creative work of S.Romanovich is the most striking one) of devotion to "European childhood".

Alexander Burganov's appeal to mythological characters does not at all seem a speculative reminder of "eternal images". In today's slang, this is a personal story. As evidenced not only by antique artifacts in the collection of his museum; and not only the exhibition-events of the last decade: "Ancient Motifs in Modern Sculpture" (the Burganov House Museum) at which he presented his "legends and myths of Ancient Greece" in 2017 and a personal exhibition held in the Antique Hall of the Museum of Archeology of the Westphalian Wilhelm University in ancient Münster. Or one of the main exhibition spaces in the Burganov House is called Pegasus (I recall that the white Pegasus, a symbol of free creativity, on a high pedestal, in fact, reigns in the courtyard of the Burganov House).

It is very important to realize that images of antiquity have been born for more than one decade in the creative work of Burganov who declarative- ly emphasizes his focus on the commonality of the cultural tradition that evolved from the cradle of Antiquity and which is, therefore, understandable to anyone who shares its high humanistic ideals ${ }^{1}$.

However, consanguinity with the European beginning is visible through the prism of other cultural kinship ties. Many of the artifacts he has created (the way how weightily and vividly Burganov's sculptures present themselves to the viewer make it possible to choose this definition without reference to the common word meaning and to speak of "the fact of art") often shine with whiteness, highlighting the classic ideal surface of a generalized form. Their outline is melodious and flowing even when they appear in "fragments" as, for example, in The Fall of Icarus or in Ancient Dreams (Nymph Arethusa, Battle of the Amazons, Marathon).

Burganov can be called a master in whose work it is difficult to distinguish the opus magnum, the work which makes you want to compare it with an integral novelistic form covering all periods of the master's life.

1. Cit. by: Burganova M. "Experience of Exhibiting Modern Sculpture" // The Art of Sculpture in the $20^{\text {th }}-21^{\text {st }}$ Centuries: Masters, Trends, Problems. Moscow: BuksMArt, 2018. P.72. 


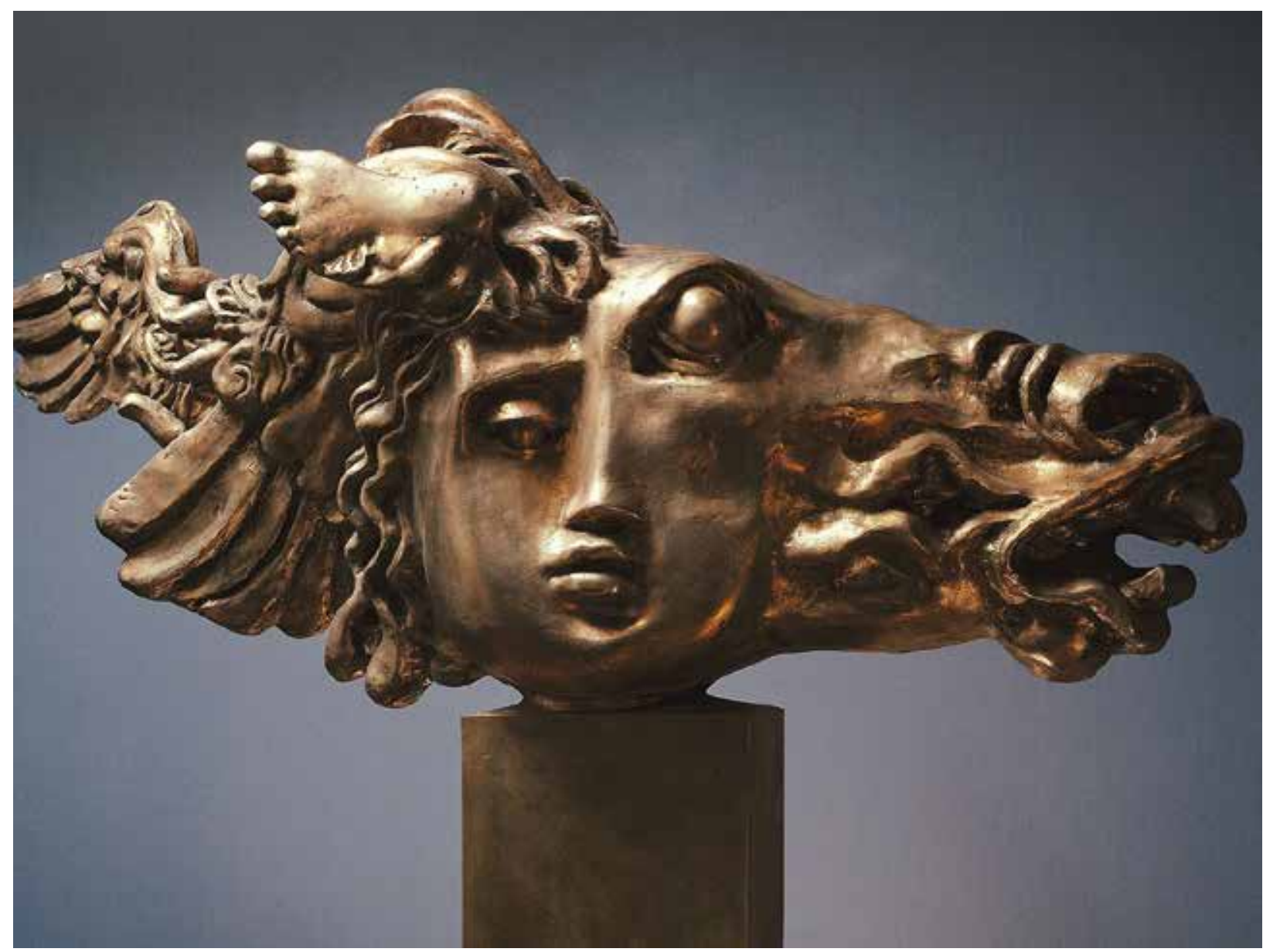

Alexander Burganov. Medusa. 2008. Red wood

In most works, intrigue is preserved, visual images do not allow the audience's consciousness to be adequately realized in the commentary word, in the detailed determination. "Life situation", "psychopathology of everyday life", or, more impressive, - "national idea"... - Burganov creates in another dimension. Invisible concepts, containing deeper meanings, are embodied in reality. And Burganov's "legends and myths of Ancient Greece" are by no means illustrations of such; they are rather very personal experiences, a sensory reaction to the subconsciously archetypal. The choice of such (from the multitude) is, in fact, an artistic message and it forms the basis for understanding the nature and mentality of our sculptor.

A Bouquet - Daphne without tragedy. A short-term and unforgettable, literally, flowering of youth. Burganov's muses are the sculptor's own improvisations.

As a cultural phenomenon, Ovid's Metamorphoses can be called the first experience of surrealism for which the transformation of familiar forms has become one of the main signs of the style. The specificity of the text encourages the reader to make efforts in order to imagine the moments of the intermedi- ate stages of reincarnation. Burganov demonstrates those for anyone to see firsthand. It becomes clear why Pierre Cardin recognized a surreal component in Burganov. (Since then, all of the completely valid attempts made before both by the artist and art critics to define the original, once a recognizable language, intonation, and meanings of his work, markings such as "magical realism", "new romanticism" had been replaced and "surrealism" became a universal tool for interpretation. Meanwhile, let's ask a professional question: how far is, for example, Ernst Fuchs's "magical realism" from the surrealistic basis? May I remind you of some facts and events in the biography of our master: personal exhibitions "Dreams Within Us. A Magic Crystal" in the Moscow Central House of Artists in 1987, "Magic Realism" in Germany in 1993 and in MMoMA in 2016, participation in the general exhibition "Sleep Reveals the Nature of Things" at the State Tretyakov Gallery in 1993, allowing both to ask and confidently answer the question posed.)

Consciousness and subconsciousness, the ApolIonian and the Dionysian turn out to be alpha and omega in the interpretation of Burganov's gallery of images. However, the environment of his Moscow 


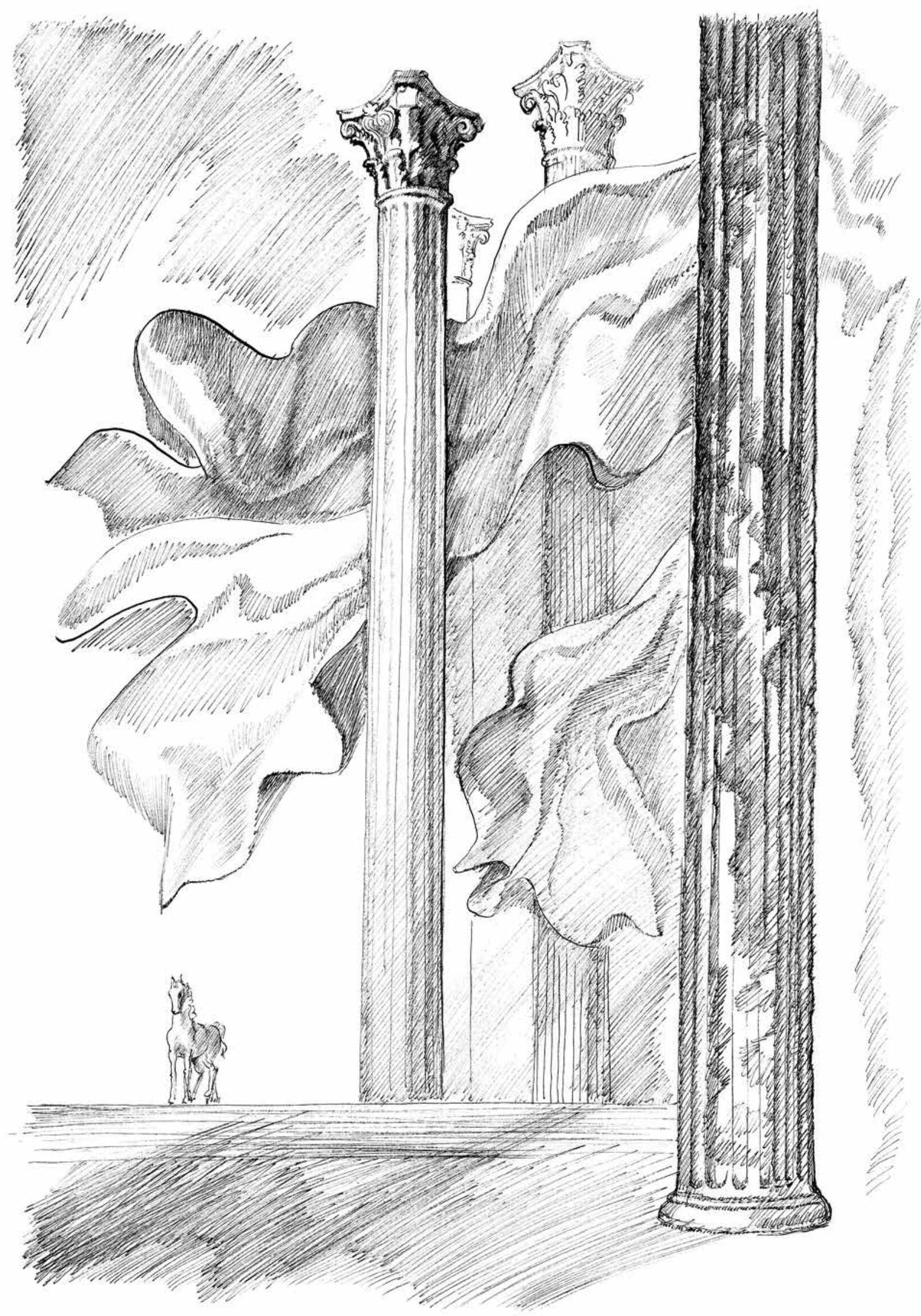

Alexander Burganov. Wind. Paper, ink 


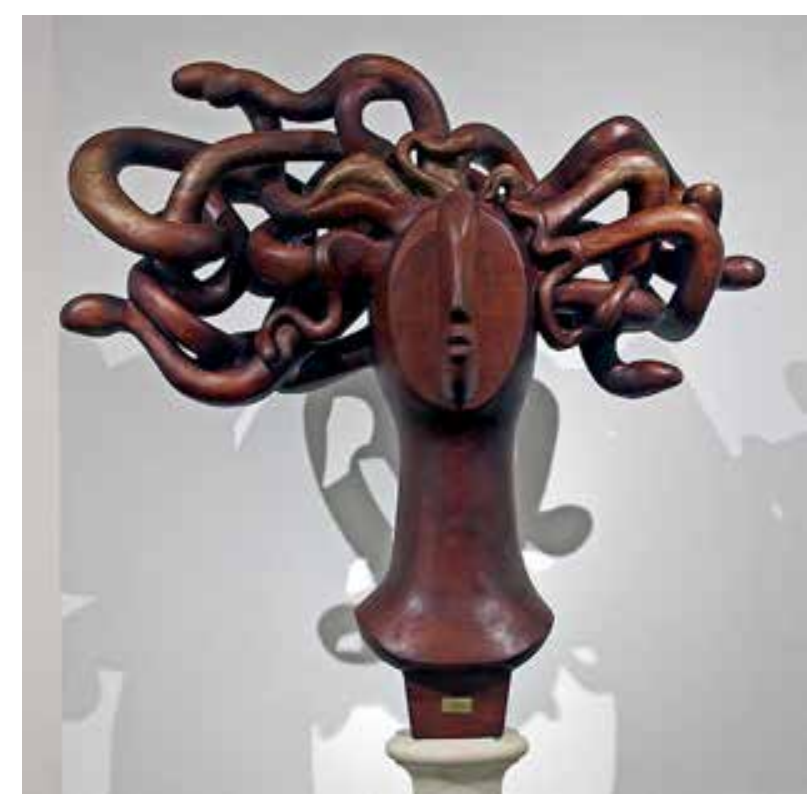

Alexander Burganov. Medusa. 2008. Red wood

House-Museum, in which the layout of the halls was thought of as an analogy of a "labyrinth", is easily associated in memory with the creation of his eldest contemporary, the Salvador Dali Theater-Museum in Figueres, which means with the whole range of cultural codes chosen from antiquity to discoveries of the twentieth century.

The variants of Chimera, not only the chthonic character of ancient myths but also one of the favorite images of sur-reality, are an example of the Dionysian. Is it worth mentioning the relevance of chimeras in modern realities? As a rule, with all the artistry and elegant invention, lightweight carnival overtones do not sound in Burganov's plastic intonation, the intonation is born from deep origins.

On canvases enclosed in frames, and in graphics, sheets with margins, surreal dream paradoxes usually appear as if on screens outside the profane, conscious location of the viewer. The sculptural variations, presenting themselves in the 3D dimension, even in distance affect directly, becoming a fact of the audience's own participation in the "happening".

Charged with dense energy, expressive and elegant, Burganov's sculptures organically exist not only in the exhibition halls but also outside them. They literally burst into space, giving it structure and materiality be it the Moscow courtyard or in the Belgian capital where, in fact, sculptures in the window display of the Burganov House at the Grand Place are no less eye-catching than the monument in the same square.

Perhaps the artist himself intuitively feels their foreign activity in the "proposed circumstances", and, therefore, tactfully creates frames-limitations as if forming and fixing a zone of their own emanation, aura. (Such an intention is not articulated. In a rational, programmatic explanation of the idea of such a motive, he is not only a "frame" but also a "cage", a tragic symbol of suffering and lack of freedom). In these structures, plastic motifs, even filled with bacchic frenzy, seem to resign, distance themselves from their surroundings, and make it easier for the viewer to read the "storyboard" of the composition, giving rise to a paradox: the fragmentation of compositions in no way deprives the images of integrity.

The art of the Russian sculptor with his international recognition and, so to speak, adaptation by the international audience, nevertheless, in my opinion, is seen in an undeniable connection with the Moscow historical environment - the proportions and rhythms of the old quarters, the mysterious romanticism, white empire columns, restrained expressiveness. It is this noble restraint (with clearly readable spectacularity), bearing in itself, within itself, dreams and passions, reality and mysticism, gives Burganov's "antique" images-metaphors a special feature that requires a comprehension of the slow, at the same time the reasonable and the emotional in order to be able to penetrate the limits of the immanent artist's impermeability. 


\section{REFERENCES}

1. Burganova, M.A., Smolenkova, Ju.A. 2020. "Alexander Burganov: a New Code of Time and Space", Nauchnoanaliticheskiy zhurnal "Dom Burganova. Prostranstvo kul'tury" [Art Literature Scientific and Analytic Journal Burganov House. The Space of Culture], vol. 16, no, 1, pp. 19-37. DOI:10.36340/2071-6818-2020-16-1-1937 (in English)

2. Sakhno, I.M. 2020. "Alexander Burganov's Alternative Worlds and Visual Ideograms",Nauchno-analiticheskiy zhurnal "Dom Burganova. Prostranstvo kul'tury" [Art Literature Scientific and Analytic Journal Burganov House. The Space of Culture], vol. 16, no, 1, pp. 38-55. DOI:10.36340/2071-6818-2020-16-1-38-55 (in English)

3. Alexander Burganov. 2013. Ancient dreams. Catalog. Archaeological Museum. Munster.

4. Burganova, M. A. 2015. "Skul'ptor Aleksandr Burganov" ["Sculptor Alexander Burganov"], Nauchno-analiticheskiy zhurnal "Dom Burganova. Prostranstvo kul'tury" [Art, Literature and Music Scientific and Analytical Journal "Burganov House. The space of culture"], no.1, pp. 223235. (in English)

5. Burganova, M.А. 2016. Скульптура Новейшего времени в музее Археологии Вестфальского университета им. Вильгельма в Мюнстере, Nauchno-analiticheskiy zhurnal "Dom Burganova. Prostranstvo kul'tury" [Art Literature Scientific and Analytic Journal Burganov House. The Space of Culture]. no. 3, pp. 39-50. (in Russian)

6. Burganova, M.A. 2010. "Syurrealizm. Russkaya traditsiya" ["Surrealism. Russian tradition"], Nauchno- analiticheskiy zhurnal "Dom Burganova. Prostranstvo kul'tury" [Art Literature Scientific and Analytic Journal Burganov House. The Space of Culture], no. 4, pp. 3452. (in Russian)

7. Zhukovsky, V.I. 2014. "Vizual'noye myshleniye v protsesse khudozhestvennogo tvorchestva" ["Visual Thinking in the Process of Artistic Creation"], Filosofiya i kul'tura [Philosophy and Culture], no. 4, pp. 618-627. DOI:10.7256/1999-2793.2014.4.10770 (in Russian)

8. Portnova, T.V. 2019. "Plasticheskiye modifikatsii A. Burganova: o vystavke «Teatr skul'ptur» v muzeye A.A. Bakhrushina" ["Plastic modifications by A. Burganov: about the exhibition "Theater of Sculptures" in the A. Bakhrushina"], Idei i idealy [Ideas and Ideals], vol. 11, no.1, part 2, pp. 406-418. DOI: 10.17212/2075-0862-2019-11.1.2-406418 (in Russian)

9. Pogozhina, S.V. 2019. "Zapadnyye vozdeystviya na kul'tury Vostoka: kontakty i konflikty" ["Western influences on the cultures of the East: contacts and conflicts"], Oriyentalistika [Orientalism], vol.2, no. 2, pp. 457-471. DOI: 10.31696/2618-7043-2019-2-2-457-471 (in Russian)

10. Turchin, V.S. 2015. "Burganovskiye motivy: ataka obrazov, deystvuyushchikh v prostranstve. Dialog s khaosom" ["Burganov's motives: an attack of images acting in space. Dialogue with chaos"], Nauchno-analiticheskiy zhurnal "Dom Burganova. Prostranstvo kul'tury" [Art Literature Scientific and Analytic Journal Burganov House. The Space of Culture], vol. 11, no. 1. pp. 236-259 (in Russian). 


\section{АЛЕКСАНДР БУРГАНОВ. В ГЛУБИНЕ НАД РЕАЛЬНОСТЬЮ.}

\section{(АНТИЧНЫЕ МОТИВЫ В КОНТЕКСТЕ ТВОРЧЕСТВА)}

Аннотация: Образы античности на протяжении не одного десятилетия рождаются в творчестве академика Александра Бурганова.

Скульптор декларативно подчеркивает свой ориентир на культурную традицию, выросшую из колыбели Античности и поэтому понятную всем, кто разделяет ее гуманистические идеалы.

В статье упоминаются персональные выставки-события последних десятилетий, на которых демонстрировались его работы: 1987 года в московском ЦДХ «Сновидение внутри нас. Магический кристалл», 1993 года - «Магический реализм» в Германии, 2017 года «Античные мотивы в современной скульптуре» (Дом-музей А.Н. Бурганова), на которой он выступил со своими «легендами и мифами Древней Греции», и прошедшая в 2013 году в античном зале Музея археологии Вестфальского университете им. Вильгельма (WWU - Westfälische Wilhelms-Universität) в Мюнстере.

Рассматриваются работы и циклы, никогда напрямую не иллюстрирующие античную мифологию, но через личное переживание, чувственную реакцию транслиру-

Общеевропейская художественная школа четыре столетия строится на поэтапном освоении мастерства, учебной программы, включившей рисунок с «античных гипсов». Историки искусств и мемуаристы не раз вспоминают начальные этапы биографий многих современных (в самом широком смысле этого определения, как это сегодня принято, - чуть ли не с импрессионистов) художников, которые отрицают, более того отторгают это «бессмысленное» и «вредное» для формирования художественного мышления занятие. А между тем можно назвать поистине звездные имена, биографии носителей которых парадоксально свидетельствуют об обратном отношении. Например, - Пабло Пикассо, Сальвадор Дали, Джорджо де Кирико. Более того, эти мастера, в причастности к ющие подсознательно архетипическое, трансцендентное. Особенностью художественных творений Бурганова является их частое пребывание в «промежуточном» состоянии, в процессе транс-формации, что позволяет легко обнаружить сюрреалистическую составляющую.

Бургановские «античные» скульптуры органично существуют не только в выставочных залах, но и за стенами таковых, будь это «московский дворик» собственного Дома-музея или площадь в Брюсселе, где скульптура в «витрине» Дома Бурганова на Гранд пляс притягивает взгляд с не меньшей властностью, чем монумент на той же площади. Благородная сдержанность (при явно считываемой зрелищности), несущая в себе, внутри себя, сны и страсти, реальность и мистику, придает бургановским «античным» образам-метафорам особость, требующую постижения медленного, одновременно разумного и эмоционального, чтобы суметь проникнуть в пределы имманентной авторской герметичности.

Ключевые слова: Александр Бурганов, античность, скульптура, сюрреализм, архетип, метафора

«современности» которых не приходится сомневаться, через образы античности интерпретировали собственную, частную, мифологию, настойчиво и часто включали изображения античных скульптурных памятников, фрагменты гипсов в свои композиции. Цадкина, Модильяни, Матисса можно ввести в немалый список мастеров европейского XX века, в творчестве которых античные мотивы стали заметными и важными вне пространства неоклассики. Художники России же за долгие десятилетия пребывания в советском пространстве демонстрируют лишь редкие образцы (один из них, наиболее яркий, на мой взгляд, - творчество С.М. Романовича) преданности «европейскому детству».

Обращение Александра Бурганова к мифологическим персонажам вовсе не кажется умозритель- 
ным напоминанием о «вечных образах». Говоря сегодняшним сленгом, это - личная история. О чем свидетельствуют не только античные артефакты в коллекции его музея; не только выставки-события последнего десятилетия: 2017 года - «Античные мотивы в современной скульптуре» (Дом-музей А.Н. Бурганова), на которой он выступил со своими «легендами и мифами Древней Греции», и - персональная, прошедшая в 2013 году в античном зале Музея археологии Вестфальского университете им. Вильгельма (WWU - Westfälische Wilhelms-Universität) в древнем Мюнстере. Или - название одного из главных выставочных пространств в «Доме Бурганова» - «Пегас» (напомню, что белый Пегас, символ свободного творчества, на высоком пьедестале, по сути, царит во дворе Дома Бурганова).

Очень важно осознать, что образы античности на протяжении не одного десятилетия рождаются в творчестве Бурганова, который декларативно подчеркивает свой ориентир на общность культурной традиций, выросшей из колыбели Античности, и поэтому понятны всем, кто разделяет ее высокие гуманистические идеалы ${ }^{1}$.

Кровное родство с европейскими истоками, впрочем, просматривается через призму других культурных родственных связей. Многие сотворенные им артефакты (то, как весомо и ярко скульптуры Бурганова предъявляют себя зрителю, позволяет избрать это определение без ссылки на общесловарное значение, а говорить о - «факте искусства») часто сияют белизной, отсвечивая классицистической идеальной поверхностью обобщенной формы. Их абрис певуч и плавен, даже когда они оказываются показанными во «фрагментах», как в «Падении Икара», или в «Античных сновидениях (Нимфа Аретуза, Битва амазонок, Марафон)», например.

Бурганова можно назвать мастером, в творчестве которого трудно выделить опус магнум, и которое хочется сравнить с цельной романной формой, охватывающей все периоды жизни мастера.

В большинстве работ сохраняется интрига, визуальные образы не позволяют зрительскому сознанию адекватно осуществляться в комментаторском слове, в детальной детерминации. «Жизненная ситуация», «психопатология обыденной жизни», или, внушительней, - «национальная идея»... - Бурганов творит в другом измерении. В реальности воплощаются невидимые понятия,

1. Цит. по: Бурганова М. Опыт экспонирования скульптуры новейшего времени //Искусство скульптуры в XX-XXI веках: мастера, тенденции, проблемы. М.: БуксМАрт, 2018. С. 72. содержащие более глубинные смыслы. И «легенды и мифы Древней Греции» у Бурганова отнюдь не иллюстрации таковых, скорее - очень личное переживание, чувственная реакция на подсознательно архетипическое. Выбор такового (из всего множества), по сути, являет художественное послание и ложится в основу понимания характера и ментальности нашего скульптора.

«Букет» - Дафна без трагизма. Кратковременное и незабываемое, в буквальном смысле, цветение юности. Музы Бурганова также оказываются авторскими импровизациями.

Овидиевские «Метаморфозы» как культурный феномен можно назвать первым опытом сюрреализма, для которого трансформация привычных форм стала одним из главных признаков стилевой принадлежности. Специфика текста побуждает читателя совершать усилия, дабы представить себе моменты промежуточных стадий перевоплощений. Бурганов же демонстрирует таковые воочию. Становится понятным, почему Пьер Карден распознал у Бурганова сюрреалистическую составляющую. (С тех пор все до этого вполне валидные попытки, и самого автора, и искусствоведов-критиков, определения самобытного, на раз узнаваемого языка, интонации и смыслов его творчества, маркировки, как, например, - «магический реализм», «новый романтизм», оказались вытесненными, а «сюрреализм» сделался универсальным инструментом для интерпретаций. Между тем, зададимся профессиональным вопросом: насколько «магический реализм» Эрнста Фукса, например, удален от сюрреалистической основы? Напомню некоторые факты-события в биографии нашего мастера: персональные выставки - 1987 года в московском ЦДХ «Сновидение внутри нас. Магический кристалл», 1993 года - «Магический реализм» в Германии и 2016 в ММоМА, участие в общей 1993 года в ГТГ экспозиции «Сон раскрывает природу вещей», позволяющие и вопрошать и уверенно отвечать на поставленный вопрос.)

Сознание и подсознание, аполлоническое и дионисийское оказываются альфой и омегой в толковании бургановской галереи образов. Но и среда его московского Дома-музея, в котором планировка залов мыслилась как аналогия «лабиринта», легко ассоциируется в памяти с творением его старшего современника - Театром-музеем Сальвадора Дали в Фигерасе, значит, и со всем избранным рядом культурных кодов от античности до открытий XX столетия. 
Примером «дионисийского» - варианты «Химеры», не только хтонического персонажа древних мифов, но и одного из излюбленных образов сюр-реальности. Стоит ли упоминать об актуальности химер в современных реалиях? При всем артистизме и изящном изобретательстве, как правило, легковесные карнавальные обертоны не звучат в бургановской пластической интонации, она рождается из глубинных истоков.

На холстах, заключенных в рамы, и в графике, с полями листов, сюрреалистические сновидческие парадоксы предстают обычно как на экранах, за пределами профанной, осознаваемой локации зрителя. Скульптурные же вариации, предъявляющие таковые в 3D-измерении, даже на дистанции воздействуют непосредственно, становясь фактом собственного зрительского участия в «происходящем».

Заряженные плотной энергией, экспрессивные и элегантные бургановские скульптуры органично существуют не только в выставочных залах, но и за стенами таковых. Они буквально врываются в пространство, придавая ему структуру и материальность, будь это «московский дворик» или в бельгийской столице, где скульптура, по сути, в витрине Дома Бурганова на Гранд пляс притягивает взгляд с не меньшей властностью, чем монумент на той же площади.

Пожалуй, и сам автор интуитивно чувствует их инородную активность в «предлагаемых об- стоятельствах», а потому тактично создает рамы-ограничения, словно образуя и фиксируя зону собственной их эманации, ауры. (Такое намерение не артикулируется. В рациональном, программном объяснении идеи подобного мотива он не только - «рама», но и - «клетка», трагический символ страдания и несвободы.) В этих структурах пластические мотивы, даже исполненные вакхической исступленностью, словно смиряются, дистанцируются от окружения и позволяют зрителю легче вчитываться в «раскадровку» композиции, рождая парадокс: фрагментарность композиций ни в коем случае не лишает образы цельности.

Искусство русского скульптора, с его международным признанием и, если можно так выразиться, адаптацией интернациональным зрителем, тем не менее, на мой взгляд, видится в несомненной связи именно с московским историческим окружением - пропорциями и ритмами старинных кварталов, таинственным романтизмом, белыми ампирными колоннами, сдержанной выразительности. Именно эта благородная сдержанность (при явно считываемой зрелищности), несущая в себе, внутри себя, сны и страсти, реальность и мистику, придает бургановским «античным» образам-метафорам особость, требующую постижения медленного, одновременно разумного и эмоционального, чтобы суметь проникнуть в пределы имманентной авторской герметичности.

\section{БИБЛИОГРАФИЯ}

1. Бурганова М.А., Смоленкова Ю.А. Александр Бурганов: новый код времени и пространства // Научно-аналитический журнал «Дом Бурганова. Пространство культуры». - 2020. - Т. 16. - №. 1. - С. 1937. DOI:10.36340/2071-6818-2020-16-1-19-37.

2. Сахно И.М. Альтернативные миры и визуальные идеограммы Александра Бурганова // Научно-аналитический журнал «Дом Бурганова. Пространство культуры». - 2020. - Т. 16. - № 1. - С. 38-55. DOI:10.36340/2071-6818-2020-16-1-38-55.

3. Александр Бурганов. Античные сновидения: Каталог / Археологический музей. - Мюнстер, 2013.

4. Бурганова М.А. Скульптор Александр Бурганов // Научно-аналитический журнал «Дом Бурганова. Пространство культуры». - 2015. - № 1. - С. 223-235.

5. Бурганова М.А. Скульптура Новейшего времени в музее Археологии Вестфальского университета им. Вильгельма в Мюнстере // Научно-аналитический журнал «Дом Бурганова. Пространство культуры». - 2016. - № 3. - С. 39-50.
6. Бурганова М.А. Сюрреализм. Русская традиция // Научно-аналитический журнал «Дом Бурганова. Пространство культуры». - 2010. - № 4. - С. 34-52.

7. Жуковский В.И. Визуальное мышление в процессе художественного творчества // Философия и культура. - 2014. -№ 4. - С. 618-627. DOI: 10.7256/19992793.2014.4.10770.

8. Портнова Т.В. Пластические модификации А. Бурганова: о выставке «Театр скульптур» в музее А.А. Бахрушина // Идеи и идеалы. - 2019. - Т. 11. - № 1. - Ч. 2. - C. 406-418. DOI: 10.17212/2075-0862-201911.1.2-406-418.

9. Прожогина С.В. Западные воздействия на культуры Востока: контакты и конфликты. Ориенталистика. 2019;2(2):457-471. DOI: 10.31696/2618-7043-20192-2-457-471.

10. Турчин В.С. Бургановские мотивы: атака образов, действующих в пространстве. Диалог с хаосом // Научно-аналитический журнал «Дом Бурганова. Пространство культуры». - 2015. - № 1. - С. 236-259. 